Int. J. Electrochem. Sci., 15 (2020) $9204-9222$

\title{
Investigation of Inhibition of Stress Corrosion Cracking of Welded Ti-6Al-4V Alloy using Electrochemical Noise
}

\author{
Yan Liu ${ }^{1, *}$, Jicai Feng ${ }^{2}$, Shuping Tan ${ }^{1}$, Yi Cheng ${ }^{1}$, Jin Hu $^{3, *}$ \\ ${ }^{1}$ State Key Laboratory of Efficient and Clean Coal-Fired Utility Boilers, Harbin Boiler Company \\ Limited, Harbin 150046, China \\ ${ }^{2}$ State Key Laboratory of Advanced Welding and Joining, Harbin Institute of Technology, Harbin \\ 150001, China \\ ${ }^{3}$ School of Materials Science and Engineering, Harbin Institute of Technology, Harbin 150001, China \\ *E-mail: liuyan_research@yeah.net, hujin@hit.edu.cn
}

doi: $10.20964 / 2020.09 .102$

Received: 2 May 2020 / Accepted: 20 June 2020 / Published: 10 August 2020

\begin{abstract}
In this study, the effect of residual stress on the stress corrosion cracking behavior of welded Ti-6Al-4V alloy was investigated by means of electrochemical noise. The residual stress is effectively relaxed by local rapid induction heating, and the higher heat treatment temperature leads to lower residual stress. The residual stress has a significant effect on the mechanical properties and sensitivity of stress corrosion cracking under the slow strain rate tensile test, which respectively increases and decreases continuously with the gradual relaxation of residual stress. The results indicate that a sample with lower residual stress shows higher corrosion resistance and later occurrence time of localized corrosion during the slow strain rate tensile test. The relaxation of residual stress significantly inhibits the stress corrosion cracking process.
\end{abstract}

Keywords: Electrochemical noise; Residual stress; welded Ti-6Al-4V alloy; Stress corrosion cracking

\section{$\underline{\text { FULL TEXT }}$}

(C) 2020 The Authors. Published by ESG (www.electrochemsci.org). This article is an open access article distributed under the terms and conditions of the Creative Commons Attribution license (http://creativecommons.org/licenses/by/4.0/). 